\title{
How to Promote the Service Quality of the Public Sector by Award Mechanism?
}

\author{
A study on the National Awards for Local Government in Australia
}

\author{
Yun-Hsiang Tien \\ School of Political Science and Public Administration, Wuhan University, Wuhan, China \\ Email: yhtien@whu.edu.cn
}

Received 2012

\begin{abstract}
The quality of service in the public sector has been a popular issue over the past two decades. All over the world, many governments and international organizations have set up some awards to evaluate the service performance of the public sector and encourage public organizations to devote themselves to improving their service quality. In Australia, the annual National Awards were established in 1986 and are run by the Department of Regional Australia, Regional Development and Local Government. This paper takes the National Awards for Local Government as an example to analyze important characteristics of this award, such as award themes, selection criteria, evaluation process, etc. At the end of this paper, some important findings will be discussed and some directions will be proposed for further studies on this topic.
\end{abstract}

Keywords: Quality of Service; Public Sector; Award Mechanism; National Awards for Local Government in Australia

\section{Introduction}

The quality of service in the public sector has been a popular issue over the past two decades. All over the world, many governments and international organizations set up some awards to evaluate the service performance of the public sector and encourage public organizations to devote themselves to improving their service quality. For example, in 2003, the UN General Assembly initiated the United Nations Public Service Awards. In Europe, the European Public Sector Award was launched in 2007 by the Bertelsmann Foundation together with the European Group of Public Administration (EGPA) and the University of Administrative Sciences in Speyer. Besides these international public service awards, there are also public service awards in many countries respectively. In Australia, the annual National Awards were established in 1986 and managed by the Department of Regional Australia, Regional Development and Local Government.

Over the past three decades, the New Public Management has swept the world, and its impacts on the reforms of Australian public sector have been especially well-known and admitted. For the public sector authorities of other countries, the practices and experiences of Australia have been considered important references. This paper argues that, the quality award is one of the effective incentives to promote the service quality of organizations and by analyzing the public service award in Australia, we could understand the efforts the Australian public sector has made on the quality of service in recent years and get some inspiration. This is the main motivation for this paper.

This paper is structured as follows. There have been some researches on the topic of the public sector quality awards, so the first part of the paper synthesizes the existing relevant studies. The second takes the National Awards for Local Government in Australia as an example to present briefly its development and current statement. The third section is the main part of this paper, and we will analyze important characteristics of the National Awards for Local Government, such as award themes, selection criteria, evaluation process, etc. Finally, a conclusion will draw together the main contents mentioned and point out some possible solutions to improve the present award mechanism. Besides, in the end of this paper the author will propose some directions for further studies on this topic.

\section{Litteratue Review}

In the field of public management, there have been some studies about the award mechanism of the public sector. For example, Bovaird and Löffler map existing pieces of evidence against an impact assessment framework and identifies the research gaps to be addressed by the academic community and public sector organizations [1]. Entwistle and Downe identify three tensions in the operation of the Beacon model and conclude that the relative persistence and success of the Beacon idea, in local government at least, is more a function of its effects on aspiration and morale than its concrete contribution to learning and improvement [2].

Hartley and Downe examine a major English award, the Beacon Scheme, and focus on its attractiveness to applicants. The research constructed a database of applications and awards of the local authorities over six years and using interviews and observation. The analysis examined trends over a changing policy context, along with differences in application rates across authorities and perceptions of the scheme. The analysis is used to construct criteria by which the attractiveness of award schemes and their effectiveness in service improvement can be conceptualized [3].

Borins discusses the possible impacts of recognition and awards programs. The paper sets out how a benefit-cost analysis of any award could be undertaken, showing the significance of time required by applicants among the cost factors, and 
concludes with recommendations about how better to manage a number of the elements of awards, such as publicity, the composition of selection committees, the award itself, feedback given applicants, and a department's comprehensive portfolio of awards [4].

$\mathrm{Wu}, \mathrm{Ma}, \mathrm{Su}$, Yang empirically analyze types and distributions of public sector innovations in China by examining more than 100 winners and finalists of the 'Innovations and Excellence in Chinese Local Governance' Awards Program. The results show that managerial, service and collaborative innovations are the main types of innovation in the Chinese public sectors, though technological and governance innovations are emerging. State and party agencies at the city and county levels in eastern China appear more innovative than their counterparts in central and western China [5].

According to the presentation above, we can find that the award mechanism of the public sector in Australia has been rarely mentioned by researchers. So, this paper can help us understand how the public sector award program functions in Australia.

\section{Presentation of the National Awards for Local Government in Australia [6]}

The National Awards for Local Government recognize, reward and promote the innovative work of local governments across Australia. The year 2012 marks the 26th year of these national awards. The Awards are run by the Department of Regional Australia, Local Government, Arts and Sport. Australian Government Departments sponsor different categories of Awards. For example, the category of the Innovative Infrastructure Development is Sponsored by the Australian Government Department of Infrastructure and Transport.

It's a pity that the information about the National Awards for Local Government on the official website is not sufficient, but this paper still tries to do its best to collect the related information as much as possible.

Judging the National Awards for Local Government in 2012 involved a two-step process. The first step was the judging of the category awards. In 2012 there were 16 categories were set up to judge applications in each category.

The following questions and criteria are asked of all project: (1) Innovation: What aspects of the project demonstrate something new? (2) Process and planning: What is unique about the process used to develop the project? For projects that directly affect the community and other stakeholders, how were those parties involved? (3) Benefits: What are the benefits of the project? Who benefits and how? (4) Transferability: What aspects or components of the project could be adapted or adopted for use by other Councils?

Some criteria for evaluating the projects submitted by local governments differ by categories. For instance, according to the national reports in 2002-2003, the projects in the category of the Sustainable Development -Tourism Development should have: (1) stimulated economic growth and helped business generate employment; (2) maximised the market exposure of an existing attraction or region; (3) included a strategy to improve the competitiveness of the region's tourism product; (4) included a study of tourism-dependent businesses to identify benchmark indicators and to measure the economic effects of tourism; (5) included strategies to improve the competitiveness of the region's tourism product.
The categories of the awards reflect the fields the Australian governments focus on in recent years. We find that there are some important issues the authorities care about for a long time and these issues comprise the dimensions as follows:

The first one is the emphasis on the rights of minorities such as women and the youths. These categories are sponsored by the Australian Government Department of Regional Australia, Local Government, Arts and Sport, and by the Australian Government Department of Education, Employment and Workplace Relations respectively. The winning projects in recent years reveal that many issues are related to labor and employment. Besides, the indigenous people's affairs are also emphasized by the authorities. Indigenous culture, social values, customary practices and aspirations are expected to be recognized and respected.

The second one is the emphasis on the sustainable development. The sustainable development is a hot issue worldwide. The categories such as Asset and Financial Management, Energy Smart, Innovation in Natural Resource Management, Land-Use Planning - Addressing Disaster Risk and Enhancing Resilience relate to the ecological, environmental, economical dimensions.

The third one focuses on the public service and infrastructure. The projects in these categories aim to ensure and provide a better life for citizens such as Active Arts, Excellence in Alcohol Management, Rural and Remote Health, Improving Services to Remote Communities, Innovative Infrastructure Development, etc.

\section{Analysis of the characteristics of the National Awards for Local Government in Australia}

After the brief presentation of the National Awards for Local Government in Australia, we try to find out some important characteristics and analyze them as follows:

- A. The importance of the collaboration among different units

In recent years, the collaboration among regions sponsored by the Australian Government Department of Regional Australia, Local Government, Arts and Sport has been listed in the categories of the award. This award recognizes non-capital city councils collaborating on a regional basis with other councils, Regional Development Australia (RDA) committees, the community or other bodies to strengthen investment and development opportunities, share resources, build regional competitive advantage and create jobs. In fact, the ideas and the results about the collaboration in other categories have been very common. For example, in 2011, the award of the category "Excellence in Alcohol Management" recognizes councils who work collaboratively with their community to respond to local alcohol issues.

- B. The use of information and technology on the work of innovation

Generally Speaking, technological innovation can help result in improvements in service delivery and cost control and make the user interfaces more friendly. From the details about the winners in 2011, we found that most of them knew well how to use the latest information technology on their innovative works. For instance, the project winning the National Award for Excellence was the Frankston Student Discount Card Scheme (Splash Card). This project was an excellent example of local government using modern technology to engage its young 
adults and gather information to connect them with local jobs and other services. sues

- $C$. The attention of the awards team to the new public is-

Compared to the past years, in 2012, local councils were given the opportunity to enter a number of new categories including Active Arts, Energy Smart, Excellence in Road Safety, Improving Services to Remote Communities, Innovation in Natural Resource Management, Land-Use Planning, Rural and Remote Health and Strength in Diversity. This means that the public affairs related to these fields become challenging problems and are more and more valued and the Awards Team pay great attention to the needs of citizens and then revise the categories of awards.

Besides, the new category "Active Arts” means that the spiritual life of citizens is emphasized as well as the material life by local governments.

- $D$. The source of innovation from the low level of the public sector

This award is exclusively for the local governments and aims to encourage them to devote themselves to the innovative service. This award implies that compared to other levels of governments, local governments play a vital role in the life of citizens and they are the main sources of the service innovation. They are responsible for not only the delivery of services, but also building communities, planning for future challenges and strengthening partnerships beyond council boundaries with business, community and all levels of government. So, it is important to tap into local input to develop creative solutions to address emerging social, economic and environmental issues.

- E. Organizations of the small size can also do well on the innovation of public affairs

According to the data in 2012, the 27 category winners were judged by independent judging panels and include 11 winners from small councils with fewer than 15,000 rateable properties. This result shows that, although it is considered that larger administrations should have more budgets and resources to undertake the innovative work, the size of the local government doesn't definitely reflect the ability to finish it. Smaller public organizations can still do well if they have good ideas and put them into practice well.

\section{Suggestions for Improving the Award Mechanism}

This paper helps us to understand the panorama of the National Awards for Local governments. However, during the process of the literature collecting and the paper writing, we find that the Awards Team should improve the the award mechanism on some aspects as follows:

- A. The disclosure of information about the award activities should be improved

The Department of Regional Australia, Local Government, Arts and Sport has made a column for the National Awards for Local Government on its website, and people can consult the media releases and the projects of award winners in recent years. However, some information that people can get from the website are limited. For example, we would like to understand the latest evaluation criteria of every category but failed. The only clue is from the data 2002-2003 on the website. As a result, the Awards Team should pay more attention to the disclosure of information, and then other countries will easier know it.
Besides, the Awards Team should also pay more attention to internal and external communication and awareness raising of citizens to let more people know the contributions the public administrations have made on public affairs innovation.

- B. The emphasis on cost savings in the service delivery

We have mentioned that the projects are evaluated by the dimensions such as innovation, process and planning, benefits, and transferability, etc. Nowadays, the pressures on public finance faced by public organizations are serious in many countries. To understand the ability of public organizations to well on the resource allocation and financial management, the Awards Team could add some criteria about the balancing cost change with change in service standards. By the award mechanism, more and more public organizations would emphasize the efficiency of fiscal control of the results achieved by the limited public expenditure.

- C. To continue to pay attention to the application in other public organizations

From the presentation before, we know that the Awards Team evaluates what aspects or components of the project could be adapted or adopted for use by other Councils during the evaluation. After the award ceremony, the Award Team should continue to pay attention to the results of innovation transferring. That is to say, it is important to care about whether the ideas of winning projects could be effectively imitated and learned by other public organizations. The Awards Team should continue to release the news and reports about the application of the winning projects in the next several years.

\section{Conclusion}

In the future, researchers could do some further studies on the issues of public service awards. For instance, researchers could do comparative studies to analyze the public sector awards among different countries in order to get the latest worldwide development of the public service innovation and to learn the experience of one another. Besides, the Awards Team could also do some surveys on the officers, public servants or citizens to understand their attitude and views toward the projects participating in the Awards. To sum up, the topic of public sector awards is still worth researching.

\section{Acknowledgment}

This paper is supported by "the Fundamental Research Funds for the Central Universities in China”, Number: 115274180.

\section{REFERENCES}

Bovaird, T., Löffler, E. More Quality through Competitive Quality Awards? An Impact Assessment Framework[J]. International Review of Administrative Sciences, 2009, 75(3):383-401.

Entwistle, T., Downe, J. Picking Winners to Define and Disseminate Best Practice[J]. Public Policy and Administration, 2005, 20(4):25-37.

Hartley, J., Downe, J. The Shining Lights? Public Service Awards as an Approach to Service Improvement[J]. Public Administration, 2007, 85(2):329-353.

Borins, S. Public Service Awards Programs: An Exploratory Analysis[J]. Canadian Public Administration, 2000, 43(3):321-342.

WU Jiannan, MA Liang, SU Ting, YANG Yuqian. Typology and Characteristics of Government Innovations: A Multi-Case Study of Winning Programs of the 'Innovations and Excellence in Chinese Local Governance'[J]. Journal of Public Management, 2011, 8(1): 94-103. 
Y.-H. TIEN

2011 National Awards for Local Government [EB/OL]. (2012/05/08) http://www.regional.gov.au/local/awards/index.aspx

本文为 2010 年度武汉大学人文社会科学“70 后”学者学术团 队建设计划项目, “中国地方政府基本公共服务体制创新研 究”成果，中央高校基本科研业务费专项资金资助。 